\title{
Bazı Alkanna Türlerinin Tohum Canlılık Testi, Çimlenme Oranı ve In Vitro Rejenerasyonu*
}

\author{
Cennet YAMAN ${ }^{* * *}$, Serkan URANBEY ${ }^{2}$, Hussein Abdullah Ahmed AHMED ${ }^{2}$, Dilek BAŞALMA ${ }^{2}$ \\ ${ }^{l}$ Yozgat Bozok Üniversitesi, Ziraat Fakültesi, Tarla Bitkileri Bölümü, Yozgat, TÜRKIYE \\ ${ }^{2}$ Ankara Üniversitesi, Ziraat Fakültesi, Tarla Bitkileri Bölümü, Ankara, TÜRKIYE
}

\begin{tabular}{|c|c|}
\hline Geliş Tarihi/Received: 08.03 .2021 & Kabul Tarihi/Accepted: 30.06 .2021 \\
\hline \multicolumn{2}{|l|}{ ORCID IID (Yazar sirasina göre / by author order) } \\
\hline (D) orcid.org/0000-0002-2364-8171 (i) orcid.org/0000-0002-031 & id.org/0000-0003-2634-6854 (1D) orcid.org/0000-0003-4748-5546 \\
\hline
\end{tabular}

Öz: Bu çalışmada, Alkanin/Şikonin (A/Ş) bakımından zengin olan Alkanna orientalis ve endemik Alkanna sieheana türlerinin tohum canlılığının test edilmesi, çimlenme yüzdesinin ve in vitro $\mathrm{A} / \mathrm{S}$ üretimine uygun kallus rejenerasyonunun belirlenmesi amaçlanmıştır. Doğadan toplanan tohumların canlılık oranları tetrazolium yöntemi ile belirlenmiştir. Her iki türe ait tohumların çimlendirmeleri üç farklı (kurutma kâğıt arasında, agarlı MS besin ortamında, torf içerisinde) uygulama ile testi edilmiştir. Her iki türün tohumların kabukları çıkartılarak çeşitli oranlarda bitki büyüme düzenleyicileri içeren Murashige ve Skoog (MS) ortamında kültüre alınmıștır. Tohumların canlılık oranları A. orientalis için \% 98.3 ve $A$. sieheana için ise \% 96.0 olarak belirlenmiştir. Çimlenme oranları sadece filtre kağıdı arasında $A$. orientalis türü $\% 8.3$ ve $A$. sieheana için \% 5.0 olarak tespit edilmiş, diğer uygulamalarda çimlenme gözlenmemiştir. In vitro uygulamalarda, en yüksek zigotik sürgün ve kök oluşum oranı sırasıyla \% 91.6 ve \% 40.3 ile $A$. orientalis türünde gözlenmiştir. Fakat en yüksek kallus oluşum oranı ise \% 75.0 ile $A$. sieheana türünde tespit edilmiştir. Sonuç olarak, her iki türünde canlılık oranlarının yüksek olmasına rağmen çimlenme oranlarının düşük, fakat in vitro üretilebilirliğinin ise mümkün olduğu tespit edilmiştir.

Anahtar Kelimeler: Alkanna orientalis, Alkanna sieheana, Alkanin/Şikonin, in vitro, tetrazolium

\section{Seed Viability Test, Germination Rate and In vitro Regeneration of Some Alkanna Species}

\begin{abstract}
In this study, it was aimed to test the seed viability of Alkanna orientalis and endemic Alkanna sieheana species rich in Alkannin/Shikonin (A/S) and to determine the germination percentage and callus regeneration suitable for in vitro $\mathrm{A} / \mathrm{S}$ production. The viability rates of seeds collected from nature were determined by the tetrazolium method. The germination rates of the seeds of both species were tested with three different applications (on filter paper, MS nutrient medium with agar, in peat). The seed coats of both species were removed, and their embryos were cultivated in Murashige and Skoog (MS) media containing plant growth regulators in various proportions. The viability rates of the seeds were found at $98.3 \%$ for $A$. orientalis and $96.0 \%$ for $A$. sieheana. Germination rates were determined only on filter paper as $8.3 \%$ for $A$. orientalis and $5.0 \%$ for $A$. sieheana, no germination was observed in other applications. The highest zygotic shoot and root formation rate were obtained from A. orientalis with $91.6 \%$ and $40.3 \%$, respectively. But, the highest callus formation rate was observed on $A$. siehenea with $75.0 \%$. As a result, it was determined that although the viability rates were high in both species, the germination rates were low, but in vitro reproducibility was possible.
\end{abstract}

Keywords: Alkanna orientalis, Alkanna sieheana, Alkannin/Shikonin, in vitro, tetrazolium

\footnotetext{
": Bu çalışma, Ankara Üniversitesi, Fen Bilimleri Enstitüsü tarafından kabul edilen birinci yazara ait "Alkanna sieheana ve A. orientalis var. orientalis Türlerinin İ Vitro Kültürü, Antioksidan Aktiviteleri İle Bazı Sekonder Metabolitlerin İncelenmesi" isimli Doktora Tez çalışmasının bir bölümünden üretilmiştir.
} 


\section{Giriş}

Boraginaceae (Hodangiller) familyasına ait olan Alkanna, otsu yapıda ve yaklaşık olarak 50 tür içeren bir cins olup (Mahmoudi ve ark., 2012), Türkiye'de Alkanna cinsi 41 takson (yaklaşık \% 80 endemizm) ile temsil edilmektedir (Davis ve ark., 1988; Güner ve ark., 2012). Alkanna türlerinden olan Alkanna orientalis gövde ve yaprakları kadifemsi tüylü olup, 100-2450 m yüksekliklerde doğal olarak yayılış gösteren sarı çiçekli yaygın bir türdür (Davis, 1978). Alkanna sieheana Rech.fil. türü ise çok yıllık 1400-1600 m yüksekliklerde doğal olarak yayılış gösteren, korolla lopları mavi renkli endemik bir türdür (Davis ve ark., 1988). Bu türlerin köklerinde birçok kullanım alanına sahip olan enantiyomerik naftokinon türevleri [Alkanin/Şikonin (A/Ş)] olan renk pigmentleri bulunmaktadır (Yaman ve ark., 2019).

Geçmişten günümüze $\mathrm{A} / \mathrm{S}$ ve türevleri tekstil, gıda, kozmetik gibi alanlarda boyama amaçlı kullanılmaktadır. Tıp ve farmakoloji alanlarında güçlü bir yara iyileştirici (Papageorgiou ve ark., 2008), anti mikrobial (antibakterial ve anti fungal) (Haghbeen ve ark., 2011; Damianakos ve ark., 2012), anti inflamatuar (Mahmoudi ve ark., 2012), anti trombotik ve sitotoksik (Cui ve ark., 2008; Sevimli-Gur ve ark., 2010), antioksidant (Assimopoulou ve Papageorgiou, 2005), enzim inhibitörü (Kajimoto ve ark., 2008) gibi çeşitli biyolojik aktivitelere sahip olduğu tespit edilmiştir. En son araştırmalarda da anti tümor özelliği olduğu belirlenmiştir (Damianakos ve ark., 2012). Ticari olarak Japonya'da ruj üretiminde (Hunter ve Kilby, 1990) kullanıldı̆̆ı gibi Çin başta olmak üzere birçok ülkede anti kanser tedavilerinde aktif olarak kullanılan bileşiklerin başında yer almaktadır (Yeh ve ark., 2015). Ayrıca, A/Ş ve türevleri Boraginaceae familyasının Alkanna, Onosma, Arnebia, Lithospermum ve Echium cinslerine ait yaklaşık 150 türünün köklerinde doğal olarak bulunduğu bilinmektedir (Kumar ve ark., 2011).

Köklerinde A/Ş bulunduran türler genellikle doğada yabani formları bulunan kültürü yapılmamış bitkilerdir. Ayrıca birçoğunun köklerindeki A/Ş miktarları hakkında bilgi yok denecek kadar azdır. Bu türlerin çoğunun çok yıllık olması ve optimum ticari $\mathrm{A} / \mathrm{S}$ üretiminin 6-7'ci yıllarında köklerinde biriktirmesi (Hunter ve Kilby, 1990) gibi sebeplerden dolayı kültür ile bu önemli fitokimyasalların ticari üretimini zorlaştırmaktadır. Ayrıca, in vivo şartlardaki bitkilerden $\mathrm{A} / \mathrm{S}$ ve türevleri elde etmek istenirse, bitkilerin köklerinden çıkartılıyor olması o türün yok olma tehtidi ile karşı karşıya gelmektedir.
Buna ek olarak, farklı lokalite ve ortamlardan toplandığı için stabil bir madde temini elde edilmemektedir. Doku kültürü teknikleri ile ise daha kısa sürede daha steril ve stabil madde elde edilmektedir.

In vitro şartlarda $\mathrm{A} / S ̧$ üretimi için bilimsel çalışmalar genellikle Lithospermum cinsinin Lithospermum erythrorhizon türü üzerinde yapılmış olup (Zhu ve ark., 2017; Auber ve ark., 2020), Echium, Arnebia ve Onosma cinlerinin türleri üzerinde de kayda değer çalışmalar mevcuttur (Bagheri ve ark., 2018; Hu ve ark., 2019; Fu ve ark., 2020). Fakat, Alkanna cinsinin türleri üzerinde sınırlı sayıda çalışma bulunmaktadır (Mita ve ark., 1994; Urbanek ve ark., 1996; Yaman ve ark., 2019). Bu nedenle, çalışmada ekonomik önemi yüksek olan $\mathrm{A} / \mathrm{S}$ içeriği bakımından zengin $A$. orientalis ve endemik A. sieheana tohumlarının canlılık testi, in vivo/in vitro ortamlarda çimlendirilmesi ve in vitro rejenerasyonu araştırılması amaçlanmıştır.

\section{Materyal ve Yöntem}

\subsection{Bitki materyali}

Alkanna orientalis (L.) Boiss var. orientalis Yozgat Bozok Üniversitesi Kampüsü 1399 m rakımdan (7 Haziran 2015) ve A. sieheana Rech.fil. ise Konya'nın Çumra ilçesi Apasaraycık köyünde 1090 m rakımdan (18 Mayıs 2015) türlerin tohumları toplanmıştır. Tür teşhisi Selçuk Üniversitesi, Fen Fakültesi, Biyoloji Bölümü'nde yapılmıştır.

\subsection{Tetrazolium testi}

A. orientalis ve $A$. sieheana tohumlarının canlılıkları tetrazolium testi ile analiz edilmiştir. Tohumlar önce oda sicaklığında 24 saat saf suda iyice şişirilmiş ve tohum kabukları çıkartılmıştır. Elde edilen embriyolar \% 1'lik 2,3,5-Triphenyl Tetrazolium Chloride (TTC) eriyiğinde $25{ }^{\circ} \mathrm{C}$ 'de 24 saat karanlıkta bekletilmiştir $(\mathrm{pH}=6-7)$. Daha sonra tohumlar birkaç kez saf su ile yıkandıktan sonra binoküler mikroskop altında incelenmiştir. Tohumların kırmızıya boyanma durumlarına göre canlılıkları tespit edilmiştir (Baydar, 2013). Embriyo taslaklarında boyanmamış bölge \% 50'den fazla olan tohumlar cansiz olarak kabul edilmiştir (Sağsöz, 2000; Santos ve ark., 2007). Boyanmış olan tohumlar ise canlı olarak kabul edilmiştir. Deneme Yozgat Bozok Üniversitesi, Ziraat Fakültesi, Tarla Bitkileri Bölümü Laboratuvarı'nda petri kapları içerisinde 4 tekerrürlü olarak kurulmuş ve her tekerrürde 25 adet tohum kullanılmıştır. Türlere ait tohumların canlılıkları \% olarak ifade edilmiştir. 


\section{3. Çimlenme testi}

Doğadan toplanan $A$. orientalis ve $A$. sieheana türlerinin olgunlaşmış (kahve renkli) tohumları standart çimlendirme testleri ISTA (International Seed Testing Association) kurallarına göre (Anonymous, 2004) 4 tekerrürlü olarak kurulmuş ve her bir tekerrürde 50 adet tohum kullanılmıştır. Çimlendirme testi öncesinde tohumlar \% 20'lik çamaşır suyu (sodyum hipoklorit içeriği \% 4 ticari çamaşır suyu) ile 20 dakika yüzey sterilizasyonu yapılmıştır (Subaşı ve Güvensen, 2010). Çimlendirme uygulamaları aşağıda belirtildiği gibi 3 farklı ortamda yapılmıştır.

1. Kurutma kâğıdında: Tohumlar petri kapları içinde kurutma kâğıtları arasında 8 saat karanlıkta $22 \pm 2{ }^{\circ} \mathrm{C}$ 'de ve 16 saat 1 ş1klı ortamda $27 \pm 2{ }^{\circ} \mathrm{C}$ 'de iklim dolabında tutularak çimlenmeye bırakılmış; 7. ve 14. gün sonunda sayımlar yapılarak, ortalama çimlenme oranı belirlenmiştir. Kökçük (radikul)'ün 2 mm'lik çıkışı çimlendirme kriteri olarak ele alınmış ve çimlenme oranları tespit edilmiştir.

2. Agarlı MS (Murashige ve Skoog, 1962) besin ortamında: Steril edilmiş tohumlar agar ortamında steril şartlarda 8 saat karanlık, $22 \pm 2{ }^{\circ} \mathrm{C}$ ve 16 saat 1 şılılı ortamda $27 \pm 2{ }^{\circ} \mathrm{C}^{\prime}$ de $0.64 \mathrm{~g} \mathrm{~L}^{-1}$ agar içeren MS besin ortamında iklim dolabında çimlenmeye bırakılmıştır. Çalışmada, 7. ve 14. gün sonunda sayımlar yapılarak, ortalama çimlenme oranı belirlenmiştir. Kökçük (radikul)'ün 2 mm'lik çıkışı çimlendirme kriteri olarak ele alınmış ve çimlenme oranları tespit edilmiştir.

3. Torf içerisinde: Tohumlar steril torf içeren magenta kapları içinde 8 saat karanlık, $22 \pm 2{ }^{\circ} \mathrm{C}$ ve 16 saat 1 şılklı ortamda $27 \pm 2{ }^{\circ} \mathrm{C}$ 'de iklim dolabında tutularak çimlenmeye bırakılmıştır. Çalışmada, 15. ve 30. gün sonunda sayımlar yapılarak, ortalama çimlenme oranı belirlenmiştir. Kotiledonun 5 mm'lik çıkışı çimlendirme kriter olarak ele alınmış ve çimlenme oranları tespit edilmiştir.

\subsection{Tohumların yüzey sterilizasyonu}

Her iki türün tohumları \% $20 \mathrm{NaOCl}$ (sodyum hipoklorit)'de 20 dakika muamele ederek, tohumların yüzey sterilizasyonu yapılmıştır. Sterilizasyon sonrası tohumlar steril saf su ile 3-4 kez durulanmıştır. En son durulamada tohumlar steril saf suda 1 saat bekletilmiş ve daha sonra tohum taslakları çıkartılmıştır.

\subsection{Besin ortamı ve kültür koşulları}

In vitro çalışmalarda, MS mineral tuzları ve vitaminleri ile \% 3 sukroz içeren \% 0.64 'lik agar kullanılmıştır. Besin ortamlarının hazırlanmasında distile saf su kullanılmış ve pH'sı $1 \mathrm{~N} \mathrm{NaOH}$ ya da $1 \mathrm{~N} \mathrm{HCl} \mathrm{kullanılarak} \mathrm{5.8'e} \mathrm{ayarlanmıştır.}$ Sterilizasyon için 1 atm basınç altında $121{ }^{\circ} \mathrm{C}$ 'de 20 dakika tutularak steril edilmiştir. Kültürler $24 \pm 1$ ${ }^{\circ} \mathrm{C}$ de ve floresan (3000 lüks) altında 16/8 saat 1şıklandırma koşullarında tutulmuştur.

\subsection{Tohumlarının in vitro kültüre alınması}

Tohum taslaklarının kültüre alınması için temel besin ortamlarının ve büyüme düzenleyicilerinin seçiminde, köklerinde A/Ş bulunan Boraginaceae familyasına ait diğer yakın akraba türlerde yapılan çalışmalar dikkate alındığında; BAP (6benzylaminopurine), KIN (kinetin), IAA (indol-3asetik asit) gibi büyüme düzenleyiciler sürgün oluşumunu teşvik etmek için kullanılmıştır (Mita ve ark., 1994; Pal ve Chaudhury, 2010; Phulwaria ve Shekhawat, 2013). Alkanna tinctoria Tausch türü için en iyi kallus rejenerasyonu 2,4-D (2,4 Diklorofenoksi asit)'in etkili olduğu bildirilmiştir (Mita ve ark., 1994). Bundan dolay1 sürgün gelişimi için $0.25 \mathrm{mg} \mathrm{L}^{-1} \mathrm{BAP}+0.1 \mathrm{mg} \mathrm{L}^{-1} \mathrm{KIN}+$ $0.25 \mathrm{mg} \mathrm{L}^{-1}$ IAA ve $0.25 \mathrm{mg} \mathrm{L}^{-1} \mathrm{BAP}+0.5 \mathrm{mg} \mathrm{L}^{-1}$ $\mathrm{KIN}+1.0 \mathrm{mg} \mathrm{L}^{-1}$ IAA, kallus gelişimi için $1.0 \mathrm{mg}$ $\mathrm{L}^{-1}$ 2,4-D ve $2.0 \mathrm{mg} \mathrm{L}^{-1}$ 2,4-D içeren MS besin ortamları kullanılmıştır. Her iki tür için zigotik sürgün ve kök oluşumu ile kallus oluşumu incelenmiş ve elde edilen veriler kültürden dört hafta sonra alınmıştır. Her bir deneme 3 tekerrürlü olarak kurulmuş, her tekerrürde 10 adet tohum taslağı kültüre alınmıştır.

\section{7. İstatiksel analizler}

Elde edilen veriler varyans analizine (ANOVA) tabi tutulmuş ve DUNCAN çoklu karşılaştırma testi ile gruplandırılmıştır (Düzgüneş ve ark., 1983). Yüzde değerler istatistiki analizden önce açı değerlerine dönüştürülmüştür. Tüm istatistiki analizler IBM SPSS Statistics 20 bilgisayar programında yapılmıştır. Ayrıca, her doku kültürü uygulamalarından elde edilen verilerin standart hataları ortalama değerlerinin yanında \pm ile verilmiştir.

\section{Bulgular ve Tartışma}

\subsection{Tetrazolium testi}

A. orientalis ve $A$. sieheana türlerinin tohumları TTC çözeltisi ile muamele edildiklerinde canlı tohumlar kırmızı renk ile boyanırken, cansız tohumlar ise açık pembe renge boyanmış veya hiç boyanma olmamıştır (Şekil 1). Tetrazolium testi sonrasi boyanma derecelerine göre tohumların canlılık oranlarının $A$. orientalis için \% 98.3, A. sieheana için \% 96.0 olduğu gözlenmiştir. 


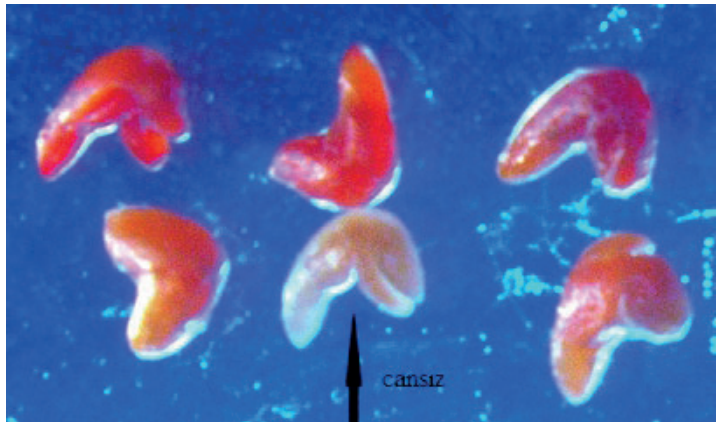

Şekil 1. A. sieheana bitkisine ait embriyoların tetrazolium testi uygulaması sonunda binoküler mikroskop görüntüsü

Figure 1. Binocular microscope image of A. sieheana embryos at the end of tetrazolium test application

\section{2. Çimlenme testi}

A. orientalis ve $A$. sieheana tohumları petri kabı, agarlı ortam ve torf gibi 3 farklı uygulamada çimlendirmeye alınmıştır. Torf ve agarlı ortam uygulamalarında çimlenme gözlenmezken, petri kabı içerisinde filtre kağıdı arasında $A$. orientalis türü $\% 8.3, A$. sieheana türü ise $\% 5.0$ çimlenme meydana geldiği gözlenmiştir (Tablo 1).

Tablo 1. Alkanna tohumlarının çimlenme oranı üzerine farklı ortamların etkisi"

Table 1. The effect of different treatments on the germination rate of Alkanna seeds*

\begin{tabular}{lcc}
\hline \multirow{2}{*}{ Uygulama } & \multicolumn{2}{c}{ Çimlenen tohum oranı $(\%)$} \\
\cline { 2 - 3 } & A. orientalis & A. sieheana \\
\hline Filtre kağıd1 & $8.3 \mathrm{a}$ & $5.0 \mathrm{a}$ \\
Agarlı ortam & $0.0 \mathrm{~b}$ & $0.0 \mathrm{~b}$ \\
Torf & $0.0 \mathrm{~b}$ & $0.0 \mathrm{~b}$ \\
\hline *: Aynı sütundaki küçük harflerle gösterilen ortalamalar arasındaki fark \\
0.05 düzeyinde önemlidir.
\end{tabular}

A. orientalis türünde ilk çimlenme belirtisi 7'nci günde meydana gelirken (Şekil 2a), $A$. sieheana türünde 12 'nci günde meydana geldiği saptanmıştır (Şekil 2b). Ayrıca A. sieheana taksonunun çimlenme sonucu meydana gelen köklerin pembe-kırmızı, A. orientalis ise daha açık pembe-kırmızı veya beyaz renkte olduğu gözlenmiştir.

Doğadan toplanan olgun Alkanna tohumlarının TTC testi sonucunda tamamına yakınının canlı olduğu göz önüne alındığında, çimlenme oranının çok düşük düzeyde olduğu bulunmuştur. Alkanna cinsi tohumlarının üzerinde çimlendirme ile ilgili literatür henüz olmayıp, çimlenme probleminin neden kaynaklandığını açıklamada yetersiz kalınmaktadır. Alkanna tohumlarının olgunlaşması bitkinin toprak kısmına yakın tohumlardan yukarı doğru olması ve hasat edildiğinde tüm tohumların aynı olgunlukta olmaması da çimlenme faaliyetini etkilemektedir. Bilindiği gibi tam olgunluğa gelmemiş canlı tohumlarda çimlenme meydana gelmemektedir. Yaman ve ark. (2015) yapmış oldukları çalışmalarında $A$. orientalis bitkisinin çiçek sapını üç eşit parçaya bölmüşler ve bu üç ayrı çiçek sapı parçalarında bulunan tohumlarda çimlendirme denemesi yapmışlardır. Çiçek sapının baş kısımdaki tohumlarda \% 2.6, orta kısımdaki tohumlarda \% 4 ve dip kisımdaki tohumlarda ise \% 13.3 çimlenme olduğunu rapor etmişlerdir. Roso ve ark. (2021) Boraginaceae familyasının türlerinden olan ve köklerinde şikonin biriktiren Echium plantagineum L. türünün tohumlar1 üzerinde yapmış oldukları çalışmada, çimlenme hızını ve gücünü dormansinin etkilediği, dormansisi kırılan tohumların çimlenme potansiyelini yaklaşı 2 katına çıkarttı̆̆ını ve çimlenme süresini kısalttığını rapor etmişlerdir. Bundan dolayı Alkanna tohumlarında çimlenme güçlügüunün sert kabuklu olmasının yanı sıra bünyesel olarak da dormansi veya çimlenme güçlüğü bulunduğu düşünülmektedir.

\subsection{A. orientalis ve Alkanna sieheana türlerinin in vitro rejenerasyonu}

Her iki türün in vitro şartlarda embriyo taslaklarından zigotik sürgün oluşum oranları kullanılan büyüme düzenleyiciye göre değişiklik göstermiştir (Tablo 2). En yüksek sürgün oluşumu A. orientalis türünde $\% 91.6$ ile $0.25 \mathrm{mg} \mathrm{L}^{-1}$

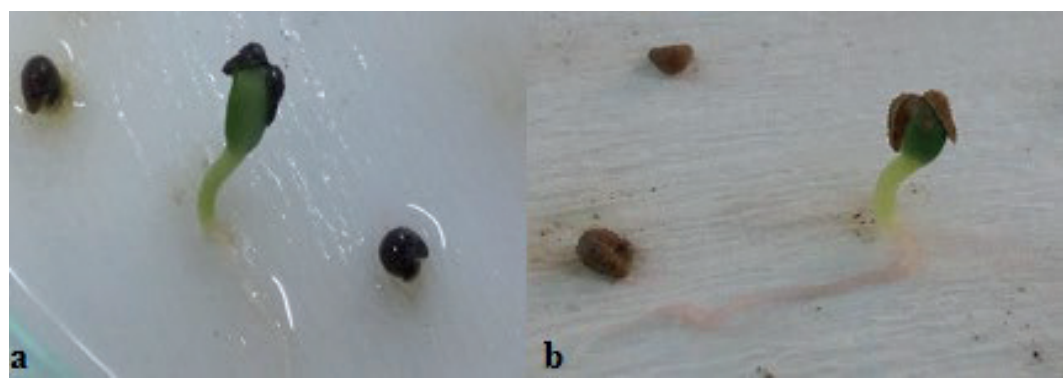

Şekil 2. Petri kabında kurutma kâğıdı arasına alınan tohumların çimlenmesi a) A. orientalis (7. gün) ve b) A. sieheana (12. gün)

Figure 2. Germination of the seeds between blotting paper in petri dish a) A. orientalis ( $7^{\text {th }}$ day) and b) $A$. sieheana $\left(12^{\text {th }}\right.$ day) 
Tablo 2. $A$. orientalis ve $A$. sieheana türünün in vitro zigotik sürgün, kök ve kallus oluşumu üzerine bitki büyüme düzenleyicilerin (sitokinin: BAP, KIN ve oksin: 2, 4-D, IAA) etkisi*

Table 2. The effect of plant growth regulators (cytokinin: BAP, KIN, and auxin: 2,4-D, IAA) on the zygotic shoot, root, and callus formation in A. orientalis and A. sieheana species in vitro*

\begin{tabular}{cccccccccc}
\hline \multicolumn{3}{c}{$\begin{array}{c}\text { Büyüme düzenleyicileri } \\
\left.(\mathrm{mg} \mathrm{L})^{-1}\right)\end{array}$} & \multicolumn{2}{c}{$\begin{array}{c}\text { Zigotik sürgün oluşum oranı } \\
(\%)\end{array}$} & \multicolumn{2}{c}{$\begin{array}{c}\text { Kök oluşum oran1 } \\
(\%)\end{array}$} & \multicolumn{2}{c}{$\begin{array}{c}\text { Kallus oluşum oran1 } \\
(\%)\end{array}$} \\
\hline BAP & KIN & $2,4-\mathrm{D}$ & IAA & A. orientalis & A. sieheana & A. orientalis & A. sieheana & A. orientalis & A. sieheana \\
\hline- & - & - & $73.0 \pm 1.52 \mathrm{~b}$ & $35.0 \pm 1.73 \mathrm{~b}$ & $40.3 \pm 0.33 \mathrm{a}$ & $0.0 \mathrm{c}$ & $0.0 \mathrm{~d}$ & $0.0 \mathrm{c}$ \\
- & 1.0 & - & $0.0 \mathrm{c}$ & $0.0 \mathrm{c}$ & $0.0 \mathrm{c}$ & $0.0 \mathrm{c}$ & $70.0 \pm 3.46 \mathrm{a}$ & $55.0 \pm 1.73 \mathrm{~b}$ \\
- & 2.0 & - & $0.0 \mathrm{c}$ & $0.0 \mathrm{c}$ & $0.0 \mathrm{c}$ & $0.0 \mathrm{c}$ & $75.0 \pm 1.73 \mathrm{a}$ & $75.0 \pm 1.73 \mathrm{a}$ & $0.0 \mathrm{c}$ \\
0.25 & 0.1 & - & 0.25 & $75.0 \pm 1.73 \mathrm{~b}$ & $56.6 \pm 2.00 \mathrm{a}$ & $23.3 \pm 1.00 \mathrm{~b}$ & $21.6 \pm 2.90 \mathrm{~b}$ & $53.3 \pm 2.00 \mathrm{~b}$ & $36.7 \pm 2.00 \mathrm{~b}$ \\
0.25 & 0.5 & - & 1.0 & $91.6 \pm 1.66 \mathrm{a}$ & $45.0 \pm 1.73 \mathrm{~b}$ & $35.0 \pm 1.73 \mathrm{a}$ & $36.6 \pm 2.00 \mathrm{a}$ & $23.3 \pm 1.00 \mathrm{c}$ & 36.32 \\
\hline
\end{tabular}

": Aynı sütundaki küçük harflerle gösterilen ortalamalar arasındaki fark $\mathrm{p}<0.01$ düzeyinde önemlidir.

$\mathrm{BAP}+0.5 \mathrm{mg} \mathrm{L} \mathrm{L}^{-1} \mathrm{KIN}+1.0 \mathrm{mg} \mathrm{L} \mathrm{L}^{-1}$ IAA içeren besin ortamında gözlenmiş ve istatiksel olarak diğer uygulamalardan farklı grupta yer almıştır. $A$. sieheana türünde ise en yüksek zigotik sürgün gelişimi \% 56.6 ile $0.25 \mathrm{mg} \mathrm{L}^{-1} \mathrm{BAP}+0.1 \mathrm{mg} \mathrm{L}^{-1}$ $\mathrm{KIN}+0.25 \mathrm{mg} \mathrm{L}^{-1}$ IAA içeren besin ortamında kaydedilmiştir (Tablo 2). Yaman ve ark. (2019) çalışmalarında $A$. orientalis türünün in vitro koşullarda zigotik sürgün oluşumunu daha düşük rapor etmişlerdir. $\mathrm{Bu}$ farklılık tohumların olgunluğundan, farklı dönemlerde ve farklı genotiplerden toplanmasından kaynaklı olabilir. Yine, Yaman ve ark. (2020) yapmış oldukları çalışmalarında, $0.25 \mathrm{mg} \mathrm{L}^{-1} \mathrm{BAP}+0.5 \mathrm{mg} \mathrm{L}^{-1} \mathrm{KIN}+$ $1.0 \mathrm{mg} \mathrm{L}^{-1}$ IAA içeren besin ortaminın $A$. orientalis türünün sürgün sayısı ve sürgün boyu üzerine $A$. siehenana türünden daha etkili olmasına rağmen $A$. siehenana türünün bu ortamdaki ortamdaki sürgünlerinde yüksek oranda şikonin içeriğinin olduğu, fakat $A$. orientalis türünde belirlenemediğini kaydetmişlerdir.

Sitokinin bitkilerde büyüme ve gelişimi teşvik eden hormon grubudur (Kiba ve ark., 2019). Besin ortamındaki sitokinin/oksin artıkça $A$. sieheana bitki büyümesini pozitif etkilerken, A. orientalis negatif etkilenmiştir. Benzer olarak, besin ortamındaki sitokinin/oksin oranı artıç̧a Arnebia hispidissima türünde sürgün oluşturma oranının arttığ1 ve özellikle BAP, KIN ve IAA içeren besin ortamlarının daha etkili olduğu rapor edilmiştir (Phulwaria ve Shekhawat, 2013). Hatta, bu büyüme düzenleyicileri içeren besin ortamında sitokinin/oksin oranı arttıkça, Arnebia hispidissima türünde sürgün oluşum yüzdesinin arttığ kaydedilmiştir (Pal ve Chaudhury, 2010). Bunun aksine, bu çalışmada BAP, KIN ve IAA içeren besin ortamında sitokinin/oksin oranı azaldıkça her iki tür içinde yüksek kök oluşumu saptanmıştır. Büyüme düzenleyici içermeyen MS (MS0) besin ortamında, zigotik sürgün gelişimi her iki tür için gözlenirken, zigotik kök oluşumu sadece $A$. orientalis (\% 40.3) türünde gözlenmiştir.

Oksin grubu büyüme düzenleyicilerinden olan 2,4-D içeren besin ortamlarında, her iki türde zigotik sürgün ve kök gelişimi gözlenmemiş, ancak yüksek oranda kallus oluşumu gözlenmiştir. Artan 2,4-D konsantrasyonu ile kallus oluşum oranı artmış ve $2.0 \mathrm{mg} \mathrm{L}^{-1}$ 2,4-D içeren besin ortamında her iki tür içinde en yüksek kallus oluşumu (\% 75) tespit edilmiştir. Fakat elde edilen kallusların yavaş geliştiği, beyaz ve şeffaf renkte olduğu gözlenmiş, rejenere ve adventif sürgün oluşturma kabiliyetinde olmadığ 1 saptanmıştır (Tablo 2, Şekil 3b ve Şekil 4c). Alkanna cinsinin

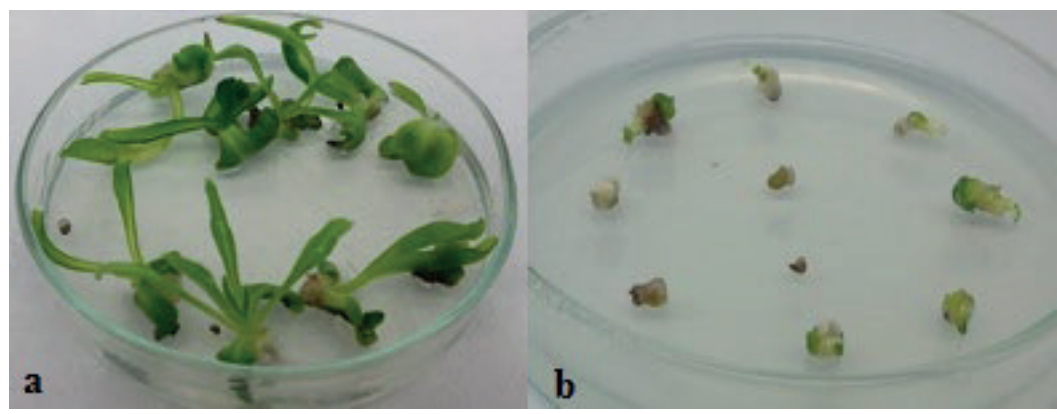

Şekil 3. A. orientalis türünün olgunlaşmış tohum taslakları eksplantlarından a) $0.25 \mathrm{mg} \mathrm{L}^{-1} \mathrm{BAP}, 0.5 \mathrm{mg}$ $\mathrm{L}^{-1} \mathrm{KIN}, 1.0 \mathrm{mg} \mathrm{L}^{-1} \mathrm{IAA}$ içeren MS besin ortamında zigotik sürgün ve kök oluşumu b) $2.0 \mathrm{mg} \mathrm{L}^{-1}$ 2,4-D içeren MS besin ortamında (10. gün) kallus oluşumu

Figure 3. From mature ovule explants of $A$. orientalis a) Zygotic shoot and root formation in MS nutrient medium containing $0.25 \mathrm{mg} \mathrm{L}^{-1} \mathrm{BAP}, 0.5 \mathrm{mg} \mathrm{L}^{-1} \mathrm{KIN}, 1.0 \mathrm{mg} \mathrm{L}^{-1} \mathrm{IAA}$ b) Callus formation in MS nutrient medium ( $10^{\text {th }}$ day) containing $2.0 \mathrm{mg} \mathrm{L}^{-1} 2,4-\mathrm{D}$ 


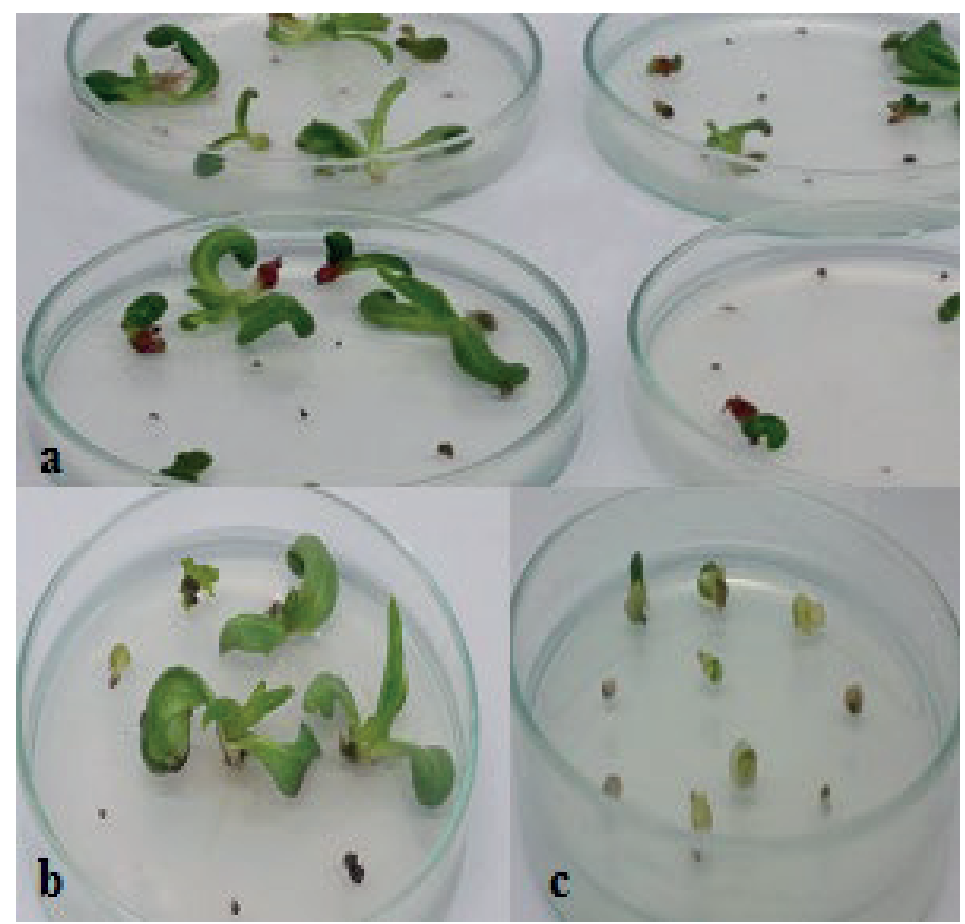

Şekil 4. A. sieheana türünün olgunlaşmış tohum taslakları eksplantlarından a) $0.25 \mathrm{mg} \mathrm{L}^{-1} \mathrm{BAP}, 0.5 \mathrm{mg}$ $\mathrm{L}^{-1} \mathrm{KIN}, 1.0 \mathrm{mg} \mathrm{L}^{-1}$ IAA ortamında zigotik sürgün ve kök oluşumu (14. gün), b) $0.25 \mathrm{mg} \mathrm{L-1}$ BAP, $0.1 \mathrm{mg}$ $\mathrm{L}^{-1} \mathrm{KIN}, 0.2 \mathrm{mg} \mathrm{l}^{-1}$ IAA ortamında zigotik sürgün ve kök oluşumu (16. gün), c) $2.0 \mathrm{mg} \mathrm{L}^{-1}$ 2,4-D ortamında (10. gün) kallus oluşumu

Figure 4. From mature ovule explants of $A$. sieheana a) Zygotic shoot and root formation (14 ${ }^{\text {th }}$ day) in $0.25 \mathrm{mg}$ $\mathrm{L}^{-1} \mathrm{BAP}, 0.5 \mathrm{mg} \mathrm{L}^{-1} \mathrm{KIN}, 1.0 \mathrm{mg} \mathrm{L}^{-1}$ IAA medium, b) Zygotic shoot and root formation in $0.25 \mathrm{mg} \mathrm{L}^{-1} \mathrm{BAP}, 0.1$ $\mathrm{mg} \mathrm{L}^{-1} \mathrm{KIN}, 0.2 \mathrm{mg} \mathrm{L}^{-1}$ IAA medium $\left(16^{\text {th }}\right.$ day), c) Callus formation in $2.0 \mathrm{mg} \mathrm{L}^{-1} 2,4-\mathrm{D}$ medium $\left(10^{\text {th }}\right.$ day)

yakın akraba cinslerine ait türlerde embriyogenik kallus oluşumunu 2,4-D’nin teşvik ettiği vurgulanmıştır (Bageri ve ark., 2011; Phulwaria ve Shekhawat, 2013; Salehian ve ark., 2014). Önceki bir çalışmada, 2,4-D’nin Arnebia hispidissima türünden kallus oluşturma üzerinde etkili olmuş ve artan konsantrasyonlarında oluşan kallusların fiziksel özelliklerinin farklı olduğu kaydedilmiştir (Pal ve Chaudhury, 2010).

Her iki türde de MS0 besin ortamında zigotik sürgün gelişimi meydana gelmiş ama üniform olmadığı gözlemlemiştir. BAP, KIN, IAA içeren ortamlarda daha sağlıklı ve üniform görünüşte olan zigotik sürgünler meydana gelmiştir (Şekil 3a ve Şekil 4a, 4b). Meydana gelen sürgünler $0.25 \mathrm{mg} \mathrm{L}^{1}$ BAP, $0.5 \mathrm{mg} \mathrm{L}^{-1} \mathrm{KIN}, 1.0 \mathrm{mg} \mathrm{L}^{-1}$ IAA ortaminda alt kültüre alınmıştır. A. orientalis ve A. sieheana türlerinden in vitro sürgün çoğaltmak ve eksplant kaynağı olarak kullanmak amacıyla her 30 günde rozet şeklinde meydana gelen sürgünlerden (Şekil 5a) tek sürgün fidesi (Şekil 5b) alt kültüre alınarak in vitro mikroçoğaltım kaynağı olabileceği

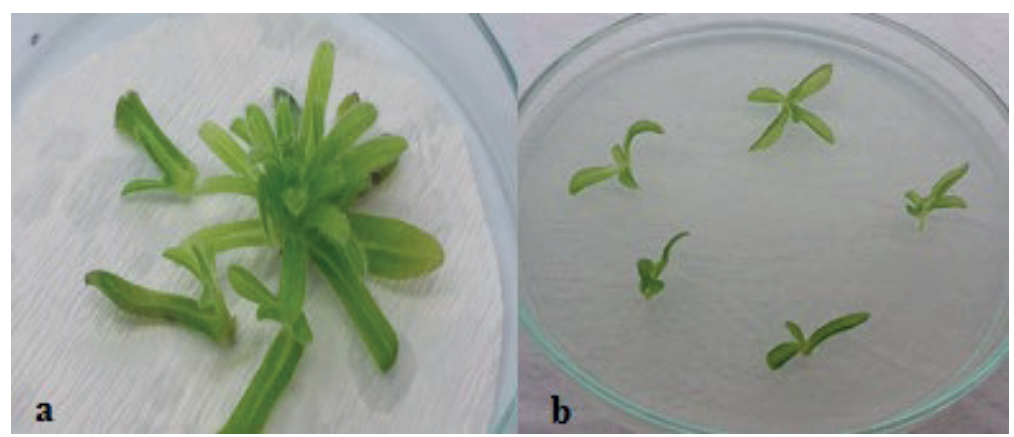

Şekil 5. A. orientalis sürgünlerin $0.25 \mathrm{mg} \mathrm{L}^{-1} \mathrm{BAP}, 0.5 \mathrm{mg} \mathrm{L}^{-1} \mathrm{KIN}, 1.0 \mathrm{mg} \mathrm{L}^{-1}$ IAA ortamında a) kültüre alındıktan 30 gün sonra gelişen fide b) fide üzerindeki sürgünler

Figure 5. A. orientalis shoots on $0.25 \mathrm{mg} \mathrm{L}^{-1} \mathrm{BAP}, 0.5 \mathrm{mg} \mathrm{L}^{-1} \mathrm{KIN}, 1.0 \mathrm{mg} \mathrm{L}^{-1}$ IAA media a) growing seedling after 30 days from culture, $b$ ) shoots on the seedling 
gözlenmiştir. Ayrıca bu mikroçoğaltılan sürgünlerinin sekonder metobolit (A/Ş gibi) üretim çalışmaları için eksplant kaynağı olarak kullanılabileceği tespit edilmiştir.

\section{Sonuç ve Öneriler}

$\mathrm{Bu}$ çalışma ile $A$. orientalis ve $A$. sieheana türlerinin tohum canlılığın yüksek olduğu, çimlendirme ortamı için özel şartlar gerektiği, tohum kabukları çıkartılarak kültüre alınmasının daha etkili olduğu gözlenmiştir. A/Ş içeriği yönünden önemli olan bu iki tür içinde $0.25 \mathrm{mg} \mathrm{L}^{-1}$ BAP, $0.5 \mathrm{mg} \mathrm{L}^{-1} \mathrm{KIN}, 1.0 \mathrm{mg} \mathrm{L}^{-1}$ IAA içeren MS besin ortamında in vitro şartlarda eksplant kaynağ 1 olarak kullanılabilecek fideler elde edilebileceği belirlenmiştir. Alkanna türlerinin tohum çimlenmesi ve in vitro uygulamaları üzerinde sınırlı sayıda çalışma bulunması, A. orientalis ve A. sieheana türleri üzerinde sunulan bu verilerin ileride bu türlerden $\mathrm{A} / \mathrm{S}$ üretimi çalışmalarını cesaretlendireceği düşünülmektedir. İleriki çalışmalarda bu türlerin olgun tohumlarının canlılık oranlarının yüksek olmasına rağmen neden çimlenme oranlarının düşük olduğunu ortaya çıkartacak fiziksel, kimyasal ve mekaniksel çalışmaların yapılması, bu konuya aydınlık getirebilir. In vitro mikrıçoğaltımı tespit edilen bu türlerin, özellikle endemik tür olan $A$. sieheana türünün in vitro ortamda sekonder metabolit üretimi üzerine farklı besin ortamlarının, bitki büyüme düzenleyicilerin, biyotik ve abiyotik streslerin etkisi incelenebilir.

\section{Kaynaklar}

Anonymous, 2004. International Rules for Seed Testing Edition. Zurich, Switzerland.

Assimopoulou, A.N., Papageorgiou, V.P., 2005. Radical scavenging activity of Alkanna tinctoria root extracts and their main constituents hydroxynaphthoquinones. Phytotherapy Research, 19(2): 141-147.

Auber, R.P., Suttiyut, T., McCoy, R.M., Ghaste, M., Crook, ,J.W., Pendleton, A.L., Widhalm, J.R., Wisecaver, J.H., 2020. Hybrid de novo genome assembly of red gromwell (Lithospermum erythrorhizon) reveals evolutionary insight into shikonin biosynthesis. Horticulture Research, 7: 82.

Bageri, S., Sanjarian, F., Haghbeen, K., Ebrahimi, M.A., 2011. Establishment of cell suspension culture from Onosma dasytrichum seed callus culture. International Research Journal of Applied and Basic Sciences, 2(10): 392-397.

Bagheri, F., Tahvilian, R., Karimi, N., Chalabi, M., Azami, M., 2018. Shikonin production by callus culture of Onosma bulbotrichom as active pharmaceutical ingredient. The Iranian Journal of Pharmaceutical Research, 17(2): 495-504.
Baydar, H., 2013. Tibbi ve Aromatik Bitkiler Bilimi ve Teknolojisi (4. Bask1). Süleyman Demirel Üniversitesi Yayınları, Isparta.

Cui, X.R., Tsukada, M., Suzuki, N., Shimamura, T., Gao, L., Koyanagi, J., Komada, F., Saito, S., 2008. Comparison of the cytotoxic activities of naturally occurring hydroxyanthraquinones and hydroxynaphthoquinones. European Journal of Medicinal Chemistry, 43(6): 1206-1215.

Damianakos, H., Kretschmer, N., Sykłowska-Baranek, K., Pietrosiuk, A., Bauer, R., Chinou, I., 2012. Antimicrobial and cytotoxic isohexenylnaphthazarins from Arnebia euchroma (Royle) Jonst. (Boraginaceae) callus and cell suspension culture. Molecules, 17(12): 1431014322.

Davis, P.H., 1978. Flora of Turkey and East Aegean Islands. Vol: 6, Edinburg University Press, Edinburgh, pp. 311-313.

Davis, P.H., Mill. R.R., Tan, K., 1988. Flora of Turkey and the East Aegean Islands. Vol 6., Edinburgh University press, Edinburgh, pp. 402-434.

Düzgüneş, O., Kesici, T., Gürbüz, F., 1983. İstatistik Metotlar1 1. Ankara Üniversitesi Ziraat Fakültesi Yayınları, No: 862, Ankara.

Fu, J.-Y., Zhao, H., Bao, J.-X., Wen, Z.-L., Fang, R.-J., Fazal, A., Yang, M.-K., Liu, B., Yin, T.-M., Pang, Y.-J., Lu, G.-H., Qi, J.-L., Yan, Y.-H., 2020. Establishment of the hairy root culture of Echium plantagineum L. and its shikonin production. 3 Biotech, 10: 429.

Güner, A., Aslan, S., Ekim, T., Vural, M., Babaç, T., 2012. Türkiye Bitkileri Listesi. NGBB ve Flora Araştırmaları Derneği Yayını, İstanbul.

Haghbeen, K., Pourmolaei, S., Mareftjo, M.J., Mousavi, A., Akbari Noghabi, K., Hosseini Shirazi, F., Meshkat, A., 2011. Detailed investigations on the solid cell culture and antimicrobial activities of the Iranian Arnebia euchroma. Journal of Biomedicine and Biotechnology, ID: 165852.

Hu, J., Leng, Y., Jiang, Y., Ni, S., Zhang, L., 2019. Effect of light quality on regeneration and naphthoquinones accumulation of Arnebia euchroma. Plant Biotechnology Reports, 13: 353360.

Hunter, C.S., Kilby, N.J., 1990. Betanin production and release in vitro from suspension cultures of Beta vulgaris. Methods in Molecular Biology, 6: 545554.

Kajimoto, S., Hori, M., Manabe, H., Masuda, Y., Shibayama-Imazu, T., Nakajo, S., Gong, X.F., Obama, T., Itabe, H., Nakaya, K., 2008. A tyrosine kinase inhibitor, beta- hydroxyisovalerylshikonin, induced apoptosis in human lung cancer DMS114 cells through reduction of dUTP nucleotidohydrolase activity. BBA-Molecular Basis of Disease, 1782(1): 41-50.

Kiba, T., Takebayashi, Y., Kojima, M., Sakakibara, H., 2019. Sugar-induced de novo cytokinin biosynthesis contributes to Arabidopsis growth under elevated $\mathrm{CO}_{2}$. Scientific Reports, 9(1): 1-15. 
Kumar, R., Sharma, N., Malik, S., Bhushan, S., Sharma, U.K., Kumari, D., Sinha, A.U., Sharma, M., Ahuja, P.S., 2011. Cell suspension culture of Arnebia euchroma (Royle) Johnston - A potential source of naphthoquinone pigments. Journal of Medicinal Plants Research, 5(25): 6048-6054.

Mahmoudi, S.Z., Seyedabadi, M., Esfahani, H.R.M., Amanzadeh, Y., Ostad, S.N., 2012. Antiinflammatory and analgesic activity of Alkanna bracteosa and Alkanna tricophila. Natural Product Research, 26(6): 564-569.

Mita, G., Gerardi, C., Miceli, A., Bollini, R., De Leo, P., 1994. Pigment production from in vitro cultures of Alkanna tinctoria Tausch. Plant Cell Report, 13(7): 406-410.

Murashige, T., Skoog, F., 1962. A revised medium for rapid growth and bio assays with tobacco tissue cultures. Physiologia Plantarum, 15(3): 473-497.

Pal, M., Chaudhury, A., 2010. High frequency direct plant regeneration, micropropagation and shikonin induction in Arnebia hispidissima. Journal of Crop Science and Biotechnology, 13(1): 13-20.

Papageorgiou, V.P., Assimopoulou, A.N., Ballis, A.C., 2008. Alkannins and shikonins: a new class of wound healing agents. Current Medicinal Chemistry, 15(30): 3248-3267.

Phulwaria, M., Shekhawat, N.S., 2013. An efficient in vitro shoot regeneration from immature inflorescence and ex vitro rooting of Arnebia hispidissima (Lehm). DC. - A red dye (Alkannin) yielding plant. Physiology and Molecular Biology of Plants, 19(3): 435-441.

Roso, R., Nunes, U.R., Müller C.A., Paranhos, J.T., Lopes, S.J., Dornelles, S.H.B., Bertagnolli, C.M., Huth, C., Forte, C.T., Menegaes, J.F., 2021. Light quality and dormancy overcoming in seed germination of Echium plantagineum L. (Boraginaceae). Brazilian Journal of Biology, 81(3): 650-656.

Sağsöz, S., 2000. Tohumluk Bilimi. Atatürk Üniversitesi Yayınlar1, Erzurum.

Salehian, H., Kabirnataj, S., Bagheri, N., Nematzadeh, G., 2014. Evaluation of capability of in vitro micropropagation in Iranian medicinal plant Echium amoenum Fish. \& C.A. Mey. International Journal of Biosciences, 40(5): 58-63.
Santos, M.A.O., Novembre, A.D.L.C., Marcos-Filho, J., 2007. Tetrazolium test to assess viability and vigour of tomato seeds. Seed Science and Technology, 35(1): 213-223.

Sevimli-Gur, C., Akgun, I.H., Deliloglu-Gurhan, I., Korkmaz, K.S., Bedir, E., 2010. Cytotoxic naphthoquinones from Alkanna cappadocica. Journal of Natural Products, 73: 860-864.

Subaş1, Ü., Güvensen, A., 2010. Seed germination studies on rare endemic Salvia smyrnaea Boiss. (Lamiaceae). Biological Diversity and Conservation, 3: 126-132.

Urbanek, H., Katarzyna, Bergier K., Marian Saniewski, M, Patykowski, J., 1996. Effect of jasmonates and exogenous polysaccharides on production of alkannin pigments in suspension cultures of Alkanna tinctoria. Plant Cell Reports, 15(8): $637-$ 641.

Yaman, C., Senkal, B.C., Toprak, G., 2015. Alkanna orientalis var. orientalis tohumlarını canlılı ve çimlenme potansiyeli. 11. Tarla Bitkileri Kongresi, Poster Bildirileri Cilt II, Çayır Mera ve Yem Bitkileri Endüstri Bitkileri T1bbi ve Aromatik Bitkiler, 7-10 Eylül, Çanakkale, s. 761-764.

Yaman, C., Uranbey, S., Ahmed, H.A., Özcan, S., Tugay, O., Başalma, D., 2019. Callus induction and regeneration of Alkanna orientalis var. orientalis and A. sieheana. Bangladesh Journal of Botany, 48(3): 633-640.

Yaman, C., Uranbey, S., Er, M., Başalma, D., 2020. In vivo ve in vitro koşullarında bazı Alkanna taksonların sekonder metabolit içerikleri ve antioksidan aktiviteleri. Türk Tarım ve Doğa Bilimleri Dergisi, 7(3): 618-626.

Yeh, Y.C., Liu, T.J., Lai, H.C., 2015. Shikonin induces apoptosis, necrosis, and premature senescence of human A549 lung cancer cells through upregulation of p53 expression. Evidence-Based Complementary and Alternative Medicine, ID: 620383.

Zhu, Y., Lu, G.H., Bian, Z.W., Wu, F.Y., Pang, Y.J., Wang, X.M., Yang, R-W, Tang, C-Y, Qi, J-L., Yang, Y.H., 2017. Involvement of LeMDR, an ATP-binding cassette protein gene, in shikonin transport and biosynthesis in Lithospermum erythrorhizon. BMC Plant Biology, 17: 198. 